\title{
HOUSING CONCEPT AND ANALYSIS OF HOUSING CLASSIFICATION
}

\author{
Inita HENILANE \\ BA School of Business and Finance, Latvia \\ Corresponding authore-mail: inita.henilane@ba.lv
}

\begin{abstract}
Housing is one of the most important life components giving shelter, safety and warmth, as well as providing a place to rest. There is a lack of unified definition for housing concept in Latvia. The aim of the study is to define the housing concept in general in Latvia and develop proposals for the classification of housing. Principal objectives are to describe and analyse the concept of "housing" and to develop the definition of housing concept in general that could be used in housing policy in Latvia for developing housing classification and analysing the aims of the housing policy. Analytical research method and comparative research method was used. The results and principal conclusions are: The developed definition of the term "housing" and the housing classification could be used in developing and implementing the housing policy as well as for statistics in Latvia and in other EU countries.
\end{abstract}

Keywords: Housing, housing concept, housing classification, housing policy, Latvia.

\section{INTRODUCTION}

Housing has an essential role in economic development of each country, accounting for 10-20\% of total economical activity in the country, as well as being to be the biggest fixed asset of households (European Commission, 2005).

The need for housing is not only one of the basic human basic, but also the indicator of living standard of the population. Today it is a topical issue that housing has to be comfortable, economical and reasonably maintainable, as well as architectonically expressive and compliant with the environment (Henilane, 2015a).

There is a limited number of research works of the housing sector in Latvia in general. However, topical research has been done by different authors (e. g. Henilane, 2015a, 2015b; Sidel̦ska, 2014; Geipele, 2014; Ijevl̦eva, 2014; Ruža, 2012; Geipele et al., 2012; Zubkovs \& Geipele, 2011; Vītola, 2010).

The aim of the study is to define the housing concept in general in Latvia and to develop proposals for the classification of housing.

The principal objectives are: to describe and to analyse the literature related to the concept "housing" in order to develop the definition of housing concept in general that could be used in housing policy, as well as to develop housing classification and analyse the aims of the housing policy.

The research paper has three sections. The first section contains the analyses of economic literature and scientific articles related to the housing concept and develops the definition of housing concept in general. The second section contains the proposed 
classification of housing, dividing it according to different characteristics. In the third section the aims of housing policy are analysed.

During the research analytical research method and comparative research method were applied.

In the Conclusion the author offers suggestions for the housing policy developers in Latvia and other EU countries in the context of housing concept and housing classification.

\section{HOUSING CONCEPT DEFINITION}

Economic literature draws special attention to the concept "housing", however, there is no common definition. The researchers explain the concept "housing" differently. For example, Smith (1776) defines the housing as a commodity; Ricardo (1817) - as tangible asset with potential return; Jevons (1871) - as fixed asset regardless the housing is owned or rented; Marshall (1890) - as a capital that is similar to the machine, if it is operated by a worker, but as a commodity if it is not operated. Researchers Grimes \& Orville 1976 explain that in the past the concept "housing" was associated with a physical phenomenon, and the policies of countries for its provision mostly are related with construction costs that may largely vary depending on the type of construction material, various housing standards and construction quality.

Within framework of housing policy the researcher Torgersen (1987) explains the concept "housing" as "the wobbly pillar under the welfare state" because in contrast to the health and education provision, the state does not see its role as the main service provider in this field.

In the course of time the approaches for characterization of the concept "housing" have changed which depends on both the change in the politics, economics and other fields. Webster's dictionary as one of the explanation for concept "housing" gives the following: housing means dwellings provided for people. Business Dictionary defines housing as building or building structure complying with requirements of laws and regulations and where the individuals with their families may live. Similar definition for the concept "housing" is provided in Macmillan Dictionary where the housing is defined as buildings for people to live in.

The concept "housing" has a similar concept - "house" which was described by Melnikas (1998) as a specific and relatively limited, physically, biologically socially close place where people and groups of people can live their biosocial life, by receiving services, performing house chores and other biosocial activity.

The author considers that nowadays more attention is focused on the benefits and costs of housing, i.e. having the housing comfortable, convenient and appropriate, but at the same time also energy-efficient; the costs of its purchase, construction and maintenance should be proportionate to the benefits that can be obtained from this housing.

Researching the housing stock as an element of regional socio-economic development Sidelska (2014) uses the concept "housing" as real estate or its part 
in the building, including non-residential building that is used for dwelling purposes all year round (..).

In the housing legislation in the Nordic countries the concept "housing" mostly is used in conjunction with the term "forms of housing" that is related with various forms of apartments (privately owned apartments, rented apartments, cooperative apartments, etc.) (Nordic Council of Ministers, 1998).

In the larger scale, in the research performed by researcher Donner (2000) regarding the housing policy in 15 European Union states where the teoretical and practical aspects of housing policy are unified, the concept "housing" is explained with various similar and mutually related concepts, i. e. dwellings, "low-cost dwellings, social housing, subsidised dwellings, sub-standard dwellings.

In Europe dwellings traditionally are defined as group of mutually related premises that is physically separated from the outer environment, and consists of walls, roof, windows and doors, engineering communications and other technical elements. Rooms must be suitable for people for independent living. The rights to use the apartment are always exclusive, because the apartment owner can decide who will be able to use the apartment besides him or her. These rights to use the apartment are strengthened more or less in the tenancy agreement. In addition, each apartment in the residential building has also a joint property share existing inside the house or internal (exterior corridor of the house, cellar, etc.) and outside of the house or external (courtyard, etc.) that belongs to apartment owners of the residential house and is used by all house owners, and that should be jointly managed. By living in the apartment its user receives various housing utilities that respond to life of the people very differently and the importance of which during the human life cycle changes.

Every apartment in relation to the person who lives there is characterized by such aspects as physical protection (for example, the roof protects against rain, cold, etc.), psychological protection (for example, can hide from other people), status (for example, use of the apartment shows social status of the household, but location and characteristics of the housing serve as a reference point for social status of persons who live in the housing), production (this is a very important aspect today because of the fact that work from home, for example, in field of modern information technologies, is very demanded), wealth (without practical value and application of the housing it creates the unit of invested capital, for example, in the apartment rental market and apartment purchase and sale market).

Regarding the concept "low-cost dwellings", there are discussions in housing policy about two concepts - "low-cost/inexpensive dwellings" and "highcost/expensive dwellings". Although there are a number of relative conceptions in defining the term "low-cost $d$ welling", there are several reference values by which it can be characterized, i.e.:

- "Inexpensive relative to production costs", which means that the rent for the apartment is determined according to its expenses and the planned profit from rent. The rent is determined by market prices, without taking into account the income of the apartment's tenant.

- "Inexpensive relative to household income", which means that by determining the rent for the apartment the income of the household is taken 
into account. In this case, one and the same apartment can be cheaper for one household, but expensive - for the other, depending on the household's income.

- "Inexpensive relative to other dwellings" contains the basic principle, that the apartments in the housing market are cheaper if they are smaller in area, older, less equipped or in worse technical state than the others. The apartment price is influenced by the location, the availability of infrastructure, population and other factors. All of these housing quality indicators reduce the benefits which the apartment user could get from the apartment, as well as in the particular case they affect the market price of the apartment.

- "Inexpensive relative to other goods" contains the basic principle, that in order to assess the costs of the particular apartment the person has the knowledge of similar or equivalent product (apartment), otherwise the same apartment can be a low-cost apartment for one household and expensive apartment for another.

- "Apparently inexpensive dwellings" include apartments for which the buyer or tenant does not pay full purchase or rent. This group of apartments cause the least discussions among the politicians in housing field. Most commonly this concept is referred to as the so-called "social dwelling". A similar example is in the case when a student lives with his or her parents in an apartment and pays partial rent for it.

Concept "social housing" is widely used in the literature of housing policy that is based not on economic criteria, but on housing policy criteria. This concept lacks clear, unified definition in European countries. Usually this definition includes both public and restricted profit rental housing. Sometimes the term is applicable to all subsidized housing. In some cases private rental housing is considered as "social housing", if the state intervenes in the market, by reducing rent fees below the market price for certain apartments. In these cases land owners are forced to accept lower profits, even losses, thereby subsidizing the tenants. This approach has resulted in a series of discussions in housing policy. Basically, the apartment as tangible value cannot be "social". Although it serves as a tool for provision of social housing policy, i.e. policy aimed at several social objectives, often also provision of financial equality.

Taking into account the above-mentioned "social dwelling" must comply with several conditions:

a) Production and/or funding costs are such that decrease the profit and partially are covered from public or private funds.

b) The price or rent that is being paid for social dwelling should be less than market price, but not necessarily less than dwelling maintenance costs.

c) Subsidies are granted for households with low-income.

Subsidized dwellings are apartments for which the production and/or funding costs are decreased with supply - side grants, annuity subsidies, interest subsidies or loans with interest rates below the market rates.

In the narrower sense the apartment is considered as subsidized as long as it is subject to the sale restrictions. In the broader sense the particular apartment should 
be considered as subsidized forever, even if these restrictions subsequently are cancelled. In this case the buyer privatizes (a part of) the subsidy. Therefore, (partial) reimbursement of subsidy is mandatory in such cases.

Sub-standard dwellings are apartments with certain physical quality, level of comfort, or the technical condition of it is lower than the determined standard. This term lacks a common definition in Europe.

At the same time it should be noted that the minimum housing standard in Europe since 1945 is that the apartment is equipped with water supply in both kitchen and toilet. Such conveniences as bathroom and central heating are not included in the minimum housing standard in European countries.

The number of sub-standard dwellings in each country depends on the definition applied by each country for sub-standard dwellings. The strictest definition is that, the larger is the part of sub-standard dwellings, which are not equipped with all the amenities, from the total number of apartments available in the country, the more support activities should be provided in the field of housing policy (Donner, 2000).

Latvian laws and regulations define various housing-related concepts, including the following ones:

- "building" - used for separately roofed buildings where people can enter and which are useful or intended for human and animal shelter or storing objects (..); "residential building" is the building where at least half of the area is used for living (if less than half of the total area of the building is used for living, it is classified as a non-residential building in accordance with the kind of use determined in the project); "one-apartment houses" which are free-standing mansions, including individual family houses, villas, ranger houses, country houses, cottages, garden houses, etc., also twin and row houses, where each apartment has its own roof and its own separate entrance, etc. (Ministru kabineta noteikumi Nr. 1620, 2009).

- "apartment" - group of premises that is equipped with appropriate engineering networks and devices, where there is at least one living room, as well as kitchen or kitchenette and sanitary room; "living space" is a living room, bedroom, dining room, workroom and spaces of similar meaning, etc. (Ministru kabineta noteikumi Nr. 340, 2015).

At the same time none of Latvian laws and regulations defines the concept "housing" regardless the fact that already since 1996, when Housing Policy Concept that should be considered as the first housing policy document after regaining independence of Latvia was approved, the housing policy, laws and regulations that regulate housing, housing programmes, etc. have been discussed. The only policy planning document, where the concept "housing" is interpreted, is in Stage I of State Support Programme 2000 "Housing Development Crediting Programme" (HDCP) where the concept "housing" is explained as complex of premises or separate premise suitable for permanent living, accommodation, apartment, mansion (Mājokl̦u politikas koncepcija, 1996; Mājokļu kreditēšanas programma. I etaps, 2000).

Broader and more modern explanation for the concept "housing" in Latvia is provided in Draft Housing Guidelines elaborated in 2005, unfortunately not adopted 
by the government, where housing is defined as "both individual family house and apartment, living rooms in hostels, in social care centres, etc. Housing consists of one or more rooms and auxiliary premises. Housing is intended for living all year round and it must have direct access to the street or to joint-use premises (staircases, common corridors, galleries, etc.). Auxiliary premises are kitchens, corridors, sanitary rooms, bathrooms, storage rooms, built-in closets. In dormitories and social care institutions as auxiliary premises besides the aforementioned also facilities of cultural and municipal interest and medical service facilities are included" (Mājoklı pamatnostādņu projekts, 2005).

The Central Statistical Bureau (CSB) for statistical purposes defines the concept "housing (housing unit)" as separated and independent place of residence, intended for living for one household, or place of residence, which is not intended for living, but which was used by the household during the census as a permanent residence. "Housing" includes occupied conventional dwellings and other housing units. Usually the housing has fixed address (Central Statistical Bureau, 2005).

Taking into account the above mentioned the author concludes that in Latvia there is no distinct link between the term "housing" defined in the laws and regulations and policy planning documents. It is not clear why within the period of 20 years no legal act has been developed to clarify the concept of housing and the related aspects. In Latvia there is a need to develop a common definition of housing, which should be set by the laws and regulations in order to address the shortcomings in existing laws and regulations and to create common terminology in the housing sector.

The author has offered a general definition for the concept of "housing" that is more suitable for the research problem - housing is a building or part of a building where a household can live all year round and which meets certain statutory requirements, including also residential address.

\section{HOUSING CLASSIFICATION}

The author has developed several types of housing classifications. The housing is classified by the housing type, size, housing amenities, location, group of population living in the housing, type of ownership rights, construction period of the housing, energy efficiency indicators; construction materials used in the exterior wall of the housing and by other features (see Table 1).

The developed types of classification of housing, by classifying them according the different characteristics, are only some of the main classifications of housing and could be supplemented by other classifications. Housing classifications could be useful for developing housing policy and implementing it, as well as for housing statistics in Latvia and also in other EU countries. 
Table 1. Housing Classifications

\begin{tabular}{|c|c|}
\hline $\begin{array}{c}\text { Type of housing } \\
\text { classification }\end{array}$ & Characteristics \\
\hline By housing type & $\begin{array}{l}\text { Room in the apartment } \\
\text { Apartment in multi-apartment residential building or non- } \\
\text { residential building } \\
\text { Multi-apartment residential building } \\
\text { Family house } \\
\text { Other }\end{array}$ \\
\hline By housing size & $\begin{array}{l}\text { One room } \\
\text { One-room apartment } \\
\text { Two-room apartment } \\
\text { Three-room apartment, and more } \\
\text { Family house } \\
\text { Other }\end{array}$ \\
\hline By housing amenities & $\begin{array}{l}\text { Housing with all amenities. } \\
\text { Housing with part of amenities } \\
\text { Housing without amenities }\end{array}$ \\
\hline By housing location & $\begin{array}{l}\text { Housing in a city } \\
\text { Housing in rural territory }\end{array}$ \\
\hline $\begin{array}{l}\text { By group of population } \\
\text { living in the housing }\end{array}$ & $\begin{array}{l}\text { Any resident } \\
\text { Persons with low-income or other social group at risk }\end{array}$ \\
\hline $\begin{array}{l}\text { By type of housing } \\
\text { ownership rights }\end{array}$ & $\begin{array}{l}\text { State-owned housing } \\
\text { Municipality-owned housing } \\
\text { Natural person's owned housing } \\
\text { Legal person's owned housing } \\
\text { Other }\end{array}$ \\
\hline $\begin{array}{l}\text { By construction period of } \\
\text { the housing }\end{array}$ & $\begin{array}{l}\text { Housing build before World War II } \\
\text { Housing built from } 1945 \text { to } 1990 \\
\text { Housing built from } 1990 \text { until now }\end{array}$ \\
\hline $\begin{array}{l}\text { By energy efficiency } \\
\text { indicators of housing }\end{array}$ & $\begin{array}{l}\text { Minimum regulatory energy performance level allowed for new } \\
\text { buildings } \\
\text { Minimum regulatory energy performance level allowed for } \\
\text { reconstructed or renovated buildings } \\
\text { Almost zero energy consumption housing } \\
\text { Other }\end{array}$ \\
\hline $\begin{array}{l}\text { By construction materials } \\
\text { used in the exterior wall of } \\
\text { the housing }\end{array}$ & $\begin{array}{l}\text { Brick wall } \\
\text { Wood } \\
\text { Brick/panel } \\
\text { Reinforced concrete / concrete } \\
\text { Lightweight concrete } \\
\text { Wood/masonry } \\
\text { Other. }\end{array}$ \\
\hline etc. & \\
\hline
\end{tabular}

Source: Developed by the author (based on Ministru kabineta noteikumi Nr. 340, 2015; Ministru kabineta noteikumi Nr. 1620, 2009; Informatīvs ziņojums par ēku renovācijas finansēšanas risinājumiem, 2013; Ėku renovācijas ilgtermiņa stratēgija, 2014; Central Statistical Bureau, 2005). 


\section{ANALYSIS OF HOUSING POLICY OBJECTIVES}

It is important to ensure certain tangible and intangible needs in the life of each individual. Provision of housing is one of the most important tangible needs of an individual besides food and clothing.

Housing policy is related to state intervention in housing market.

Researcher Lund (2006) in his research points out that there are a lot of housing policy systems, however, each of them contains:

- regulatory procedures according to which the housing problems are identified;

- analysis of causes of housing problems;

- ways of how and why the state should intervene in the housing market.

Donner (2000) in her research characterizes the housing policy in a narrow sense as physical human shelter, whereas in broader sense it includes all other aspects that are essential for adequate or optimal living conditions. Provision of minimum housing standard is contribution in the welfare of the whole society.

The basic issue of housing policy, which is discussed a lot among politicians, is whether the state should intervene in the housing market in order to influence the housing situation for a particular part of the society.

It should be agreed with the opinion of researcher Donner (2000) that the main aim of housing policy is to prevent or to correct housing consumption by ensuring access for each household to the housing appropriate in terms of size and quality for adequate price.

There are several sub-objectives that are subordinated to the main aim of the housing policy and they very often cause discussions among politicians. They provide certain benefits to the society as a whole, as well as to the households as individuals.

Donner (1995) analyses sub-objectives of the housing policy not as the only rational and social housing policy objectives, but as instruments which may serve for achieving the main aim of the housing policy, i.e.:

1. To extend the sector of housing owners.

The main benefits of the implementation of this objective are:

- Accumulation/bequest of capital.

Residents are more likely keen to invest the capital in housing property than to rent housing, as they want to leave their property to next generation. At the same time there are risks of mortgage loan repayment and of price fluctuations in the housing market.

- Protection against unforeseen circumstances.

After the repayment of the mortgage loan, the repayment and the costs of housing for the housing owners reduce, because they should cover only housing maintenance costs.

- Conservation of capital/capital gains.

Real estate ensures the option to invest it in deposits for a fixed period and to receive interest.

- Cost decrease. 
If it is considered that the rental apartment is being funded throughout its life cycle, then the apartment property that is funded by mortgage loan leads to lower total financing cost.

- Long-term security of tenure.

- Protection against increase of housing costs in the future.

- Improved social prestige.

- Freedom (financial freedom, when the mortgage loan is repaid; freedom with regard to the improvement of housing, e.g. the choice of materials, etc.).

- Better maintenance of the housing, etc.

2. To replace private housing rental sector with public (social) rental sector.

With regard to this sub-objective there are lots of discussions among the politicians, and the author agrees with the view expressed by (Donner, 1995) that housing market is not conceivable without private housing rental market. The state has to ensure adequate housing consumption and intervene in the housing market as little as possible.

3. To expand the supply of new housing construction.

New housing construction is market-oriented instrument of housing policy, at the same time it should be taken into account that low-income households need additional subsidies for ensuring availability of new housing.

4. To redistribute the supply of existing housing in a more efficient way.

In the redistribution of housing there is difference between public and private rental market for low-income households. Within public rental market the state or municipality has to assess the size of housing against the size of a household and perform adequate housing distribution. Whereas, it is much more difficult to influence the private housing market and in certain cases it can happen mostly through the regulatory framework.

5. To improve the existing housing standard by the construction of new housing

6. To decrease housing expenditure against the household income level.

This objective is related to the availability of housing for each household, and includes the decrease of housing expenditure and increase of housing income.

7. To improve housing conditions for households by covering their basic needs.

Housing policy as well as any other policy may not function separately from other policies, it is closely related also with policies in other fields that have the impact on the general aim of housing policy and the sub-objectives such as income (re)distribution policy, wealth distribution policy, economic and labour market policies, spatial and regional policy, energy policy (Donner, 1995).

The author believes that the state has to intervene in that part of the housing market which does not work in an effective manner. The main task of the housing policy in Latvia is to ensure that the state government in cooperation with local governments and private sector look for new possibilities of attracting financial resources for housing sector in long-term, especially for the investment in energy efficiency of multi-apartment building because of their poor technical conditions in Latvia in general, as well as to ensure the support through different services or financial instruments for direct social risk groups or groups at risk (for example, people with low-income, pensioners, large families, students, young families). It is also important to improve the housing legislation in Latvia, e.g. to integrate the term 
"housing concept" in housing legislation and to find the possibilities of building new public housing.

\section{CONCLUSION}

There are many housing concepts and it is possible to classify housing according to different characteristics. The author has developed a general definition of housing concept that can be used in housing policy, which is especially important for Latvia because there is no definition of housing concept in any of normative regulations in Latvia.

The author has developed proposals for the classifications of types of housing, by classifying them by different characteristics. The classifications of housing can be supplemented with other classifications and be used in developing and implementing the housing policy as well as in housing statistics in Latvia and in other EU countries.

The housing policy is related to the process of state intervention in housing market.

The author believes that the state has to intervene in the part of the housing market that does not work in an effective manner as well as to ensure the support for social risk groups or groups at risk through different services or instruments.

The author's further research in this sector will follow.

\section{REFERENCES}

Business Dictionary. (n.d.). Housing. Retrieved September 5, 2016, from http://www.businessdictionary.com/definition/housing.html

Central Statistical Bureau. (2005). Housing (Population Counting). Retrieved from http://www.csb.gov.lv/statistikas-temas/termini/majoklis-tautas-skaitisana-39317.html

Donner, C. (1995). Das Ende der Wohnbauförderung/Versuch eines wohnpolitischen Gersamtsystems. Vienna. 337 p.

Donner, C. (2000). Housing policies in the European Union. Theory and Practice. Vienna. 566 p.

European Commission. (2005). Housing Finance Systems for Countries in Transition: principles and examples. Retrieved from

http://www.unece.org/fileadmin/DAM/hlm/documents/Publications/housing_finance_system.pdf

$\bar{E} k u$ renovācijas ilgtermiņa stratēgija [Long Term Investment Strategy for Building Renovation]. (2014). Riga: Cabinet of Ministers. Retrieved February 12, 2015, from http://ec.europa.eu/energy/sites/ener/files/documents/2014_article4_lv_latvia.pdf

Informatīvs ziņojums par ēku renovācijas finansēšanas risinājumiem [Informative report of the financial solutions for building renovation]. (2013). Retrieved from https://em.gov.lv/files/majokli/IZ_6.doc

Ijevl̦eva, K. (2014). Latvijas patērētāju finanšu lietpratība mājokḷu kredītu tirgū mārketinga kontekstā [Latvian consumer financial literacy housing loan market marketing context] (Doctoral thesis, University of Latvia). Retrieved from https://luis.lu.lv/pls/pub/luj.fprnt?l=1\&fn=F245926210/Ksenija\%20Ijevleva\%202014.pdf

Jevons, W. S. (1871). The Theory of Political Economy. London: Macmillan and Co.

Geipele, S. (2014). Nekustamā īpašuma tirgus vadīšanas sistēmas attīstība Latvijā [Development of the real estate management system in Latvia] (Doctoral thesis, Riga Technical University). Retrieved from http://www.rtu.lv/component/option,com_docman/task,doc_download/gid, 10992/sandas-geipeles-darba-kopsavilkums.pdf 
Geipele, I., Geipele, S., \& Stamure, I. (2012). Finansēšanas modeļi dz̄̄vojamā fonda renovācijai Latvijā [Financing models for residential building renovation in Latvia]. Monograph. Riga: Riga Technical University.

Grimes, Jr., \& Orville, F. (1976). Housing for Low Income Urban families. Economics and Policy in the Developing World, IBRD Research Publication. Baltimore: Te Johns Hopkins University Press.

Henilane, I. (2015a). The Evaluation of housing situation in Latvia. In XVI Turiba University International Conference "Towards Smart, Sustainable and Inclusive Europe: Challenges for Future Development,” (pp. 93-106). Riga, Latvia. ISSN 1691-6069.

Henilane, I. (2015b). Review of housing mortgage lending policy practices in Latvia. Journal of Business and Management, 10, 59-69. ISSN 1691-5348.

Mājoklı kreditēšanas programma. I etaps [Housing Development Crediting Programme I stage]. (2000). Cabinet of Ministers. Retrieved form: http://likumi.lv/doc.php?id=10094

Mājoklı politikas koncepcija [Housing Policy Conception]. (1996). Cabinet of Ministers. Retrieved from: http://polsis.mk.gov.lv/documents/520

Mājoklı politikas pamatnostādņu projekts [Housing Policy Guidelines Project]. (2005). Retrieved form http://www.lps.lv/images/objects/committee_files/sittings/198dd93415Pamatnostadnes\% 20majokliem.doc

Lund, B. (2006). Understanding Housing Policy. Bristol: The Policy Press. 262 p.

Macmillan Dictionary. (n.d.). Housing. Retrieved from http://www.macmillandictionary.com/dictionary/british/ housing

Marshall, A. (1890). Principles of Economics. London: Macmillan and Co.

Melnikas, B. (1998). Management and modernization of housing facilities: specific features of central and eastern European countries. Facilities, 16(11), 326-333. http://dx.doi.org/10.1108/02632779810233601

Merriam - Webster dictionary. (n.d.). Housing. Retrieved from http://www.merriamwebster.com/dictionary/housing

Ministru kabineta noteikumi Nr. 340. (2015). Noteikumi par Latvijas būvnormatīvu LBN 211-15 "Dzīvojamās èkas". Retrieved from http://likumi.lv/ta/id/275016-noteikumi-par-latvijasbuvnormativu-lbn-211-15-dzivojamas-ekas-

Ministru kabineta noteikumi Nr. 1620. (2009). Noteikumi par būvju klasifikāciju. Retrieved from http://likumi.lv/doc.php?id=202919

Nordic Council of Ministers. (1998). Housing law in the Nordic countries. Copenhagen. 397 p. ISBN 92-893-0236-4.

Ricardo, D. (1817). On the Principles of Political Economy and Taxation. London: John Murray, Albemarle Street.

Ruža, O. (2012). Analysis and estimations of residential real estate in the regional aspect (Doctoral thesis, Daugavpils University). Retrieved from http://dnl.biblio.du.lv/promocijas/promocijas\%20darbs_O_Ruza.pdf

Smith, A. (1776). An Inquiry into the Nature and Causes of the Wealth of Nations. London: Methuen \& Co., Ltd.

Sidel̦ska, A. (2014). Dzīvojamais fonds kā regiionu sociālekonomiskās attīstības elements [Housing stock as an element of socio-economic developmnet of regions] (Doctoral thesis, Latvia University of Agriculture). Retrieved from http://llufb.llu.lv/dissertation-summary/regionaleconomics/A_Sidelska_prom_darba_kopsavilkums_2014_LLU.pdf

Torgersen, U. (1987). Housing: the wobbly pillar under the welfare state. In B. Turner, J. Kemeny \& L. Lundqvist (Eds.), Between State and Market: Housing in the Post-industrial Era, Stockholm: Almqvist and Wiksell, pp. 116-126.

Vītola, K. (2010). Econometric assessment of Latvian real estate market impact on the Latvian economy (Doctoral dissertation, University of Latvia). Retrieved from https://luis.lu.lv/pls/pub/wct.doktd?l=1

Zubkovs, V., \& Geipele, I. (2011). Directions of the Innovative Development of Latvian Housing. In the $8^{\text {th }}$ International Conference "Environmental Engineering”, (pp. 1032-1037). Vilnius, Lithuania. Retrieved from http://old.vgtu.lt/leidiniai/leidykla/Enviro2011/Articles/4/1032_1037_Zubkovs_V_other.pdf 


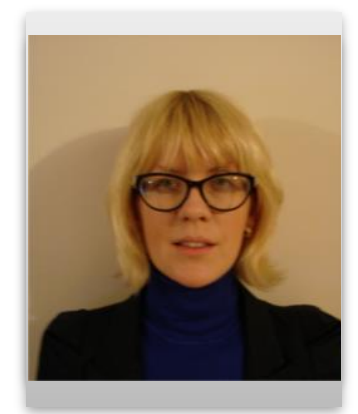

Inita Henilane received the Master degree in social science in 2002 from Riga Technical University. She was a Doctoral student with Riga Technical University from 2002-2009. Since 2015, she has continued studies at the School of Business and Finance.

Since 2016, she is a project manager with Ādaži Council.

She has more than 13 years of experience in working in public (governmental) sector.

She is the author of 7 scientific publications. 